\title{
Pulmonary sequestration associated with congenital pulmonary airway malformation
}

\author{
Zahira A. De León-Ureña ${ }^{1 *}$, Stanislaw Sadowinski-Pine², Lourdes Jamaica-Balderas ${ }^{1}$ and \\ Jaime Penchyna-Grub ${ }^{3}$ \\ ${ }^{1}$ Servicio de Neumología; ${ }^{2}$ Servicio de Patología; ${ }^{3}$ Servicio de Cirugía de Tórax y Endoscopia. Hospital Infantil de México Federico Gómez, Mexico \\ City, Mexico
}

\begin{abstract}
Background: Congenital pulmonary malformations are a rare cause of neonatal morbidity. Some of them have a common origin, which allows the identification of combined lesions. Its diagnosis can be made prenatally by ultrasound, with the limitation that this study is performed in specialized centers and depends on the expertise of the operator. The association of pulmonary sequestration and congenital malformation of the airway has been described in approximately 40-60 cases since its first description in 1949. Many lesions are not perceptible in intrauterine life, and in the neonatal period, there are recurrent respiratory symptoms that in some cases are associated with a congenital pulmonary malformation. Case report: We report the case of a young infant, who was diagnosed with pulmonary sequestration at 24 weeks of gestational age, undergoing intrauterine surgical treatment with a report of complete resolution of the malformation in posterior ultrasounds. She was valued by pediatric pneumology at four months of age, where angiotomography was performed, and the presence of pulmonary sequestration was confirmed by lobectomy. The histopathological study reported extralobar pulmonary sequestration with congenital malformation of the pulmonary airway type 2. The histopathological study identified these combined lesions. The treatment of choice was surgical. Conclusions: Upon the confirmation of a malformation, we emphasize the importance of performing screening to search for other that could be associated.
\end{abstract}

Key words: Pulmonary sequestration. Congenital pulmonary airway malformation. Ultrasound.

\section{Secuestro pulmonar asociado a una malformación congénita de la vía aérea pulmonar}

\section{Resumen}

Introducción: Las malformaciones pulmonares congénitas son una causa poco frecuente de morbilidad neonatal. Algunas de ellas tienen un origen común, lo que permite identificar lesiones combinadas. Su diagnóstico puede realizarse de forma prenatal mediante ultrasonido, con las limitaciones de que solo se realiza en centros especializados y que depende de la pericia del operador. La asociación entre el secuestro pulmonar y la malformación congénita de la vía aérea se ha descrito aproximadamente en 40-60 casos desde 1949, cuando se observó por primera vez. Muchas lesiones no son perceptibles en la vida intrauterina. Sin embargo, en el periodo neonatal se presentan síntomas respiratorios recurrentes que en algunos

Correspondence:

*Zahira A. De León-Ureña

E-mail: zahalt24@ hotmail.com
Date of reception: 16-05-2017

Date of acceptance: 20-10-2017

DOI: 10.24875/BMHIME.M18000031
Avaliable online: 10-08-2018 Bol Med Hosp Infant Mex. 2018;75:105-112 www.bmhim.com 
casos están asociados con una malformación pulmonar. Caso clínico: Se presenta el caso de una lactante diagnosticada con secuestro pulmonar a las 24 semanas de edad gestacional. Recibió tratamiento quirúrgico intrauterino con reporte de resolución completa de la malformación en ultrasonidos posteriores. Fue valorada por neumología pediátrica a los 4 meses de edad. Se realizó una angiotomografía y se confirmó la presencia de secuestro pulmonar, por lo que se realizó una lobectomía. El estudio histopatológico reportó secuestro pulmonar extralobar con malformación congénita de la vía aérea pulmonar tipo 2. Estas lesiones combinadas se identificaron mediante un estudio histopatológico. El tratamiento de elección fue quirúrgico. Conclusiones: Ante la confirmación de una malformación, destaca la importancia de realizar la búsqueda de otras malformaciones que pudieran estar asociadas.

Palabras clave: Secuestro pulmonar. Malformación congénita de la vía aérea pulmonar. Ultrasonido.

\section{Introduction}

Congenital malformations of the lower airways are infrequent. The estimated annual incidence is 30 to $42 \mathrm{ca}-$ ses per 100,000 persons or from 0.6 to $2.2 \%$ of all the patients admitted to general hospitals ${ }^{1}$. The use of prenatal ultrasound allows an early approach, by identifying the malformation in $10 \%$ of cases at birth, while $14 \%$ are diagnosed in adolescence due to a radiological finding or chronic symptoms of the lower airway ${ }^{2}$. Pulmonary sequestration is an abnormal segment of bronchopulmonary tissue supplied by an anomalous artery of systemic origin. Congenital pulmonary airway malformation (CPAM), formerly known as cystic adenomatoid malformation (CAM), is a hamartomatous alteration of lung development caused by the replacement of the small airways and lung parenchyma by cysts. The association of both malformations is infrequent. Approximately 60 cases have been reported in the international literature ${ }^{3}$.

\section{Case report}

The case of a 4-month-old female patient, daughter of young, healthy, non-consanguineous parents is presented. Perinatal history: 30 -year-old mother, primigravida, normoevolutive pregnancy with adequate prenatal control. Six ultrasounds were performed, one of them detected a lesion suggestive of lung sequestration at week 24 of gestational age. The patient underwent intrauterine surgical treatment, and the sequestration resolution was reported at week 35 . A female infant was born by cesarean section, without complications at birth. The infant has a complete immunization schedule and an adequate psychomotor development.

The pneumology department evaluated the patient due to her history of pulmonary sequestration. Her chest $\mathrm{X}$-ray was assessed in anteroposterior and lateral projections, collimated; the X-ray had an adequate penetration quality, the trachea was slightly displaced to the right, five right and left intercostal spaces were visible, clear costophrenic and cardiophrenic angles, and well-preserved bone and soft structures. In the lateral projection, the cardiac silhouette was displaced to the right, and the presence of a retrocardiac opacity at the lung segment eight was noticed (Figure 1). Because of this finding, the patient was admitted with the diagnosis of pulmonary malformation under study and probable sequestration for diagnostic confirmation and prompt treatment.

On physical examination, the patient was alert, active and well hydrated. The head was normocephalic with normal scalp hair pattern, no masses; the neck had a normal shape, movable with no abnormal adenopathies. The expansion of the thorax was symmetric, without intercostal retractions; auscultation of the lungs revealed normal vesicular breath sounds without crackles; heart auscultation revealed normal heart sounds without murmurs. The abdomen was soft, depressible and painless, no masses or organomegaly were detected. Pelvic examination revealed normal external genitalia regarding sex and age; the extremities were symmetrical, movable and with adequate peripheral pulses, no edema, clubbing or acrocyanosis. The skin was normal in appearance, texture, and temperature. Neurological examination did not reveal focal neurological deficit or peritoneal irritation signs, modified Glasgow scale 15/15.

In laboratory studies, the following results were obtained: coagulation tests: PT $11.5 \mathrm{~s}$, PTT $30.4 \mathrm{~s}$; complete blood count: hemoglobin $(\mathrm{Hb}) 11.8 \mathrm{~g} / \mathrm{dl}$, hematocrit (Hct) $36 \%$, leukocytes count $7,500 / \mathrm{mm}^{3}$, neutrophils $22 \%$, lymphocytes $65 \%$, monocytes $11 \%$, eosinophils $2 \%$, erythrocytes $4.9 \times 10^{6} / \mathrm{ul}$, platelets $336 \times 10^{9} /$.

A thoracic CT angiography was performed, A heterogeneous ovoid cystic lesion was found in the lung window axial and coronal sections with poor enhancement after contrast. The rest of the parenchyma showed an increase in density, except in the left posterior basal part. In the arterial phase, a nutritional vessel originated from the thoracic segment of the aorta at the T11 level, surrounds the lesion, additionally, another vessel from the left pulmonary veins was observed (Figure 2). 


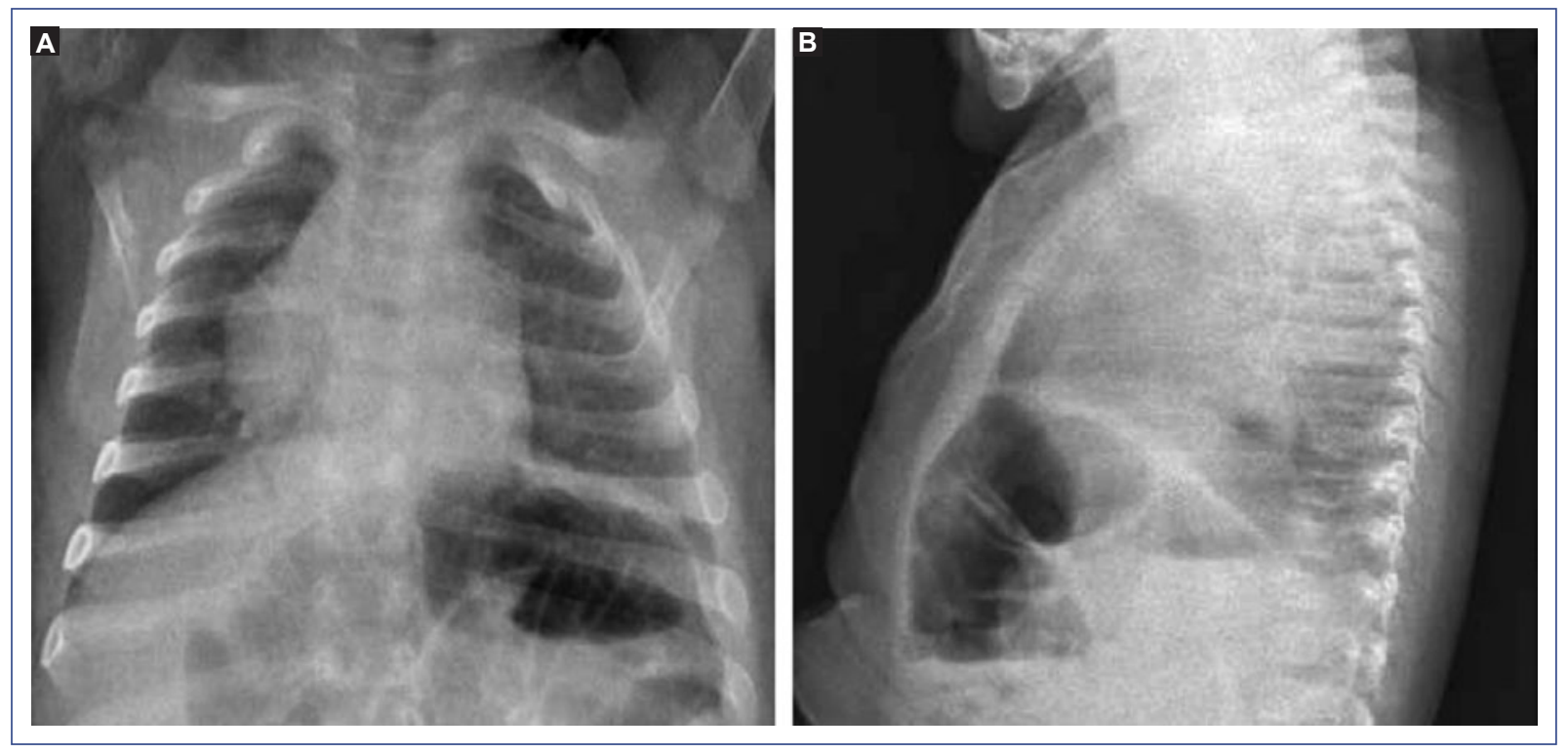

Figure 1. Chest $\mathrm{x}$-ray. A. Posteroanterior projection showing the cardiac silhouette displaced slightly to the right. B. Radiopacity at the lung segment 8 of the left lower lobe in lateral projection.

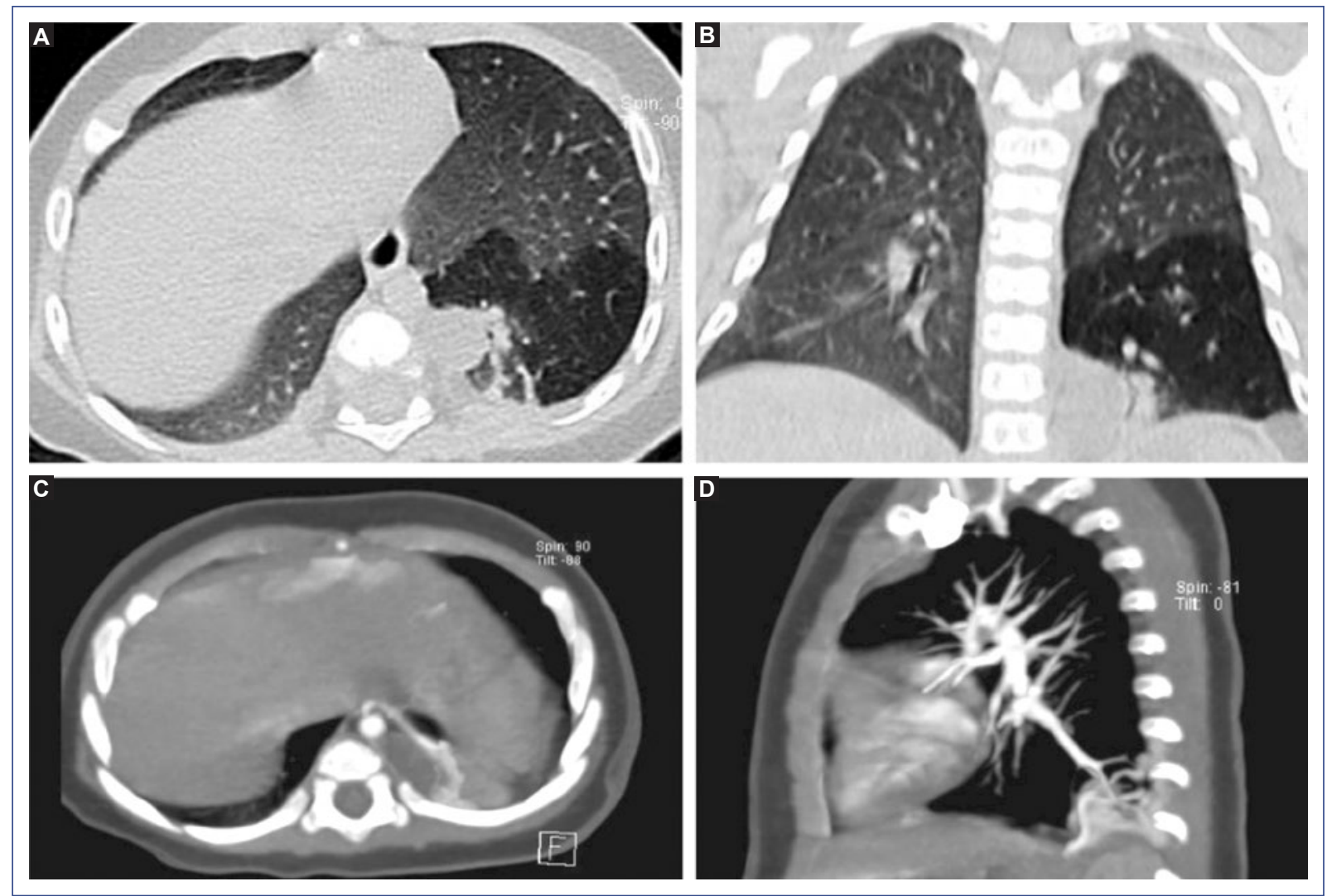

Figure 2. CT angiography. Lung parenchyma window, axial (A) and coronal (B) sections. Heterogeneous aspect due to the presence of an ovoid lesion with $21 \times 10 \times 23 \mathrm{~mm}$ of size, cystic appearance (5 Hounsfield units), with poor enhancement after contrast (19 Hounsfield units); opacific ation is observed. Increased density of the rest of parenchyma, but in the left posterior basal part where it is hypodense. Arterial phase, axial (C) and sagittal (D) sections. It can be observed a nutritional vessel from the aorta-thoracic segment at the level of the eleventh thoracic vertebra-that surrounds the lesion. Also, another vessel that originates from the left pulmonary veins can be noticed. 


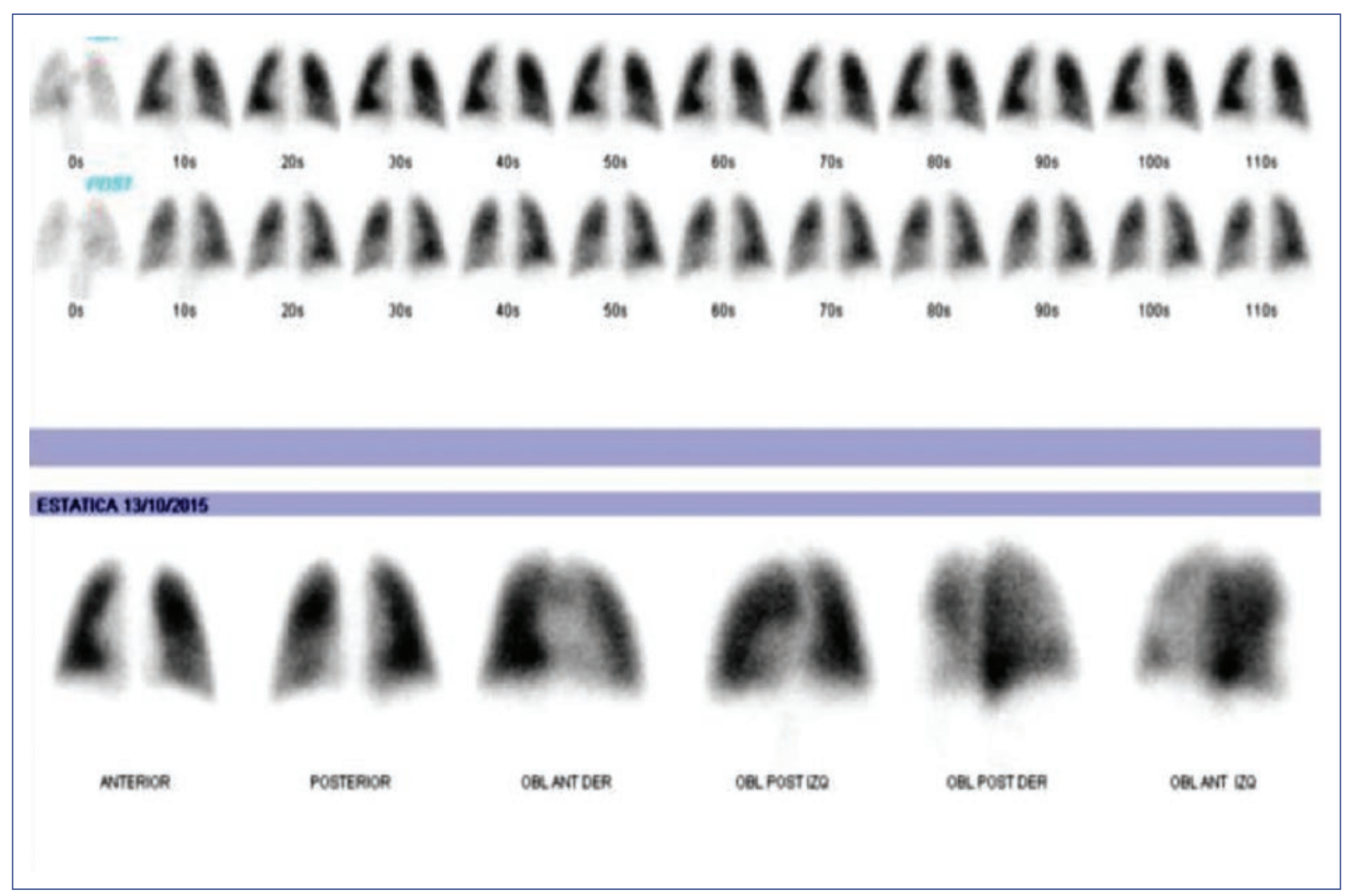

Figure 3. Pulmonary scan with $99 \mathrm{mTc}$ albumin macroaggregates. There is an increase in perfusion in the hilar and right basal region (increased radiopharmaceutical uptake in the dynamic phase).

A pulmonary scan with $99 \mathrm{mTc}$ albumin macroaggregates was performed to assess the ventilation/perfusion of the compromised lung area. In this study, an increase in perfusion in the hilar and right basal region was observed (Figure 3). The nuclear medicine department recommended the realization of an RBC nuclear scan, which reported data suggestive of pulmonary sequestration in the lower lobe of the left lung (Figure 4). Subsequently, a posterolateral thoracotomy and lobectomy were performed, and a left basal extralobar pulmonary sequestration was diagnosed postoperatively. The following surgical findings were reported: permeable left subclavian vein, left basal supradiaphragmatic extralobar pulmonary sequestration with a nutritional vessel from the abdominal aorta, and a thoracic wall cyst.

The pathology report of the specimen obtained by left lobectomy with cyst resection described extralobar pulmonary sequestration in the lower lobe of the left lung with congenital pulmonary malformation type 2; pulmonary vascular disease grade $\mathrm{B}$, according to Rabinovitch classification, and a bronchogenic cyst (Figures 5 and 6).
The patient showed an adequate medical recovery and clinical progress after surgical treatment. One month after the procedure, chest X-ray showed no apparent alterations (Figure 7).

\section{Discussion}

There is a group of abnormalities that have been named bronchopulmonary foregut malformations, and include bronchogenic cysts, pulmonary sequestration, duplication cysts and congenital malformation of the pulmonary airway ${ }^{3}$.

Pulmonary sequestration is a hamartomatous alteration of lung development caused by the replacement of the small airway and lung parenchyma by cysts. Its origin probably is related to a vasculogenesis disorder in the affected area or an occlusion of the vessels that should supply it ${ }^{4,5}$. Moreover, congenital pulmonary airway malformation (CPAM) is an abnormal hamartomatous disorder that courses with a proliferation of bronchioles that form cysts instead of alveoli. It is characterized by a multicystic mass with pulmonary tissue and proliferation of bronchial structures, that is 


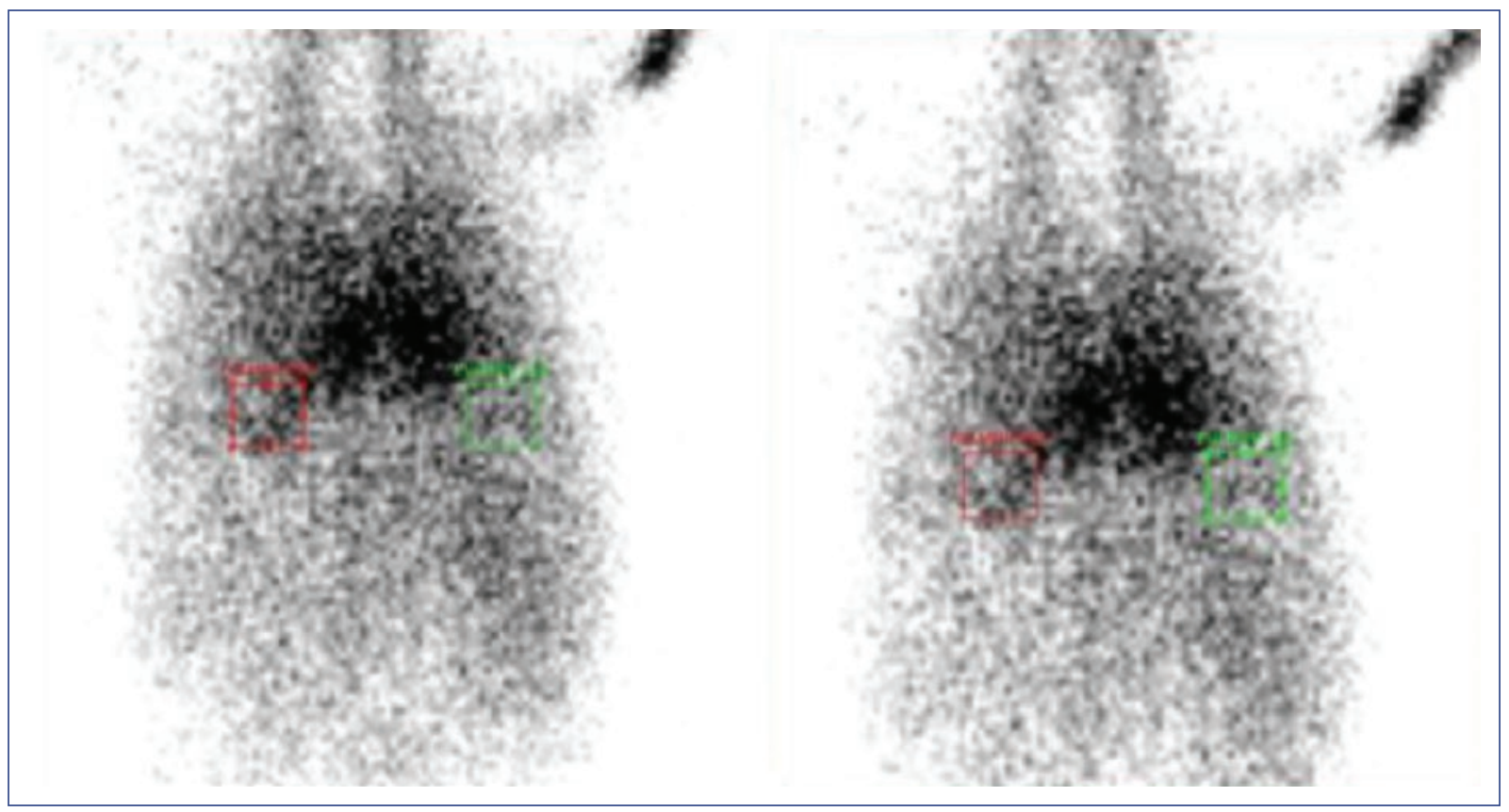

Figure 4. RBC nuclear scan. Data are suggestive of pulmonary sequestration in the lower lobe of the left lung. Cardiac silhouette is displaced to the right side.

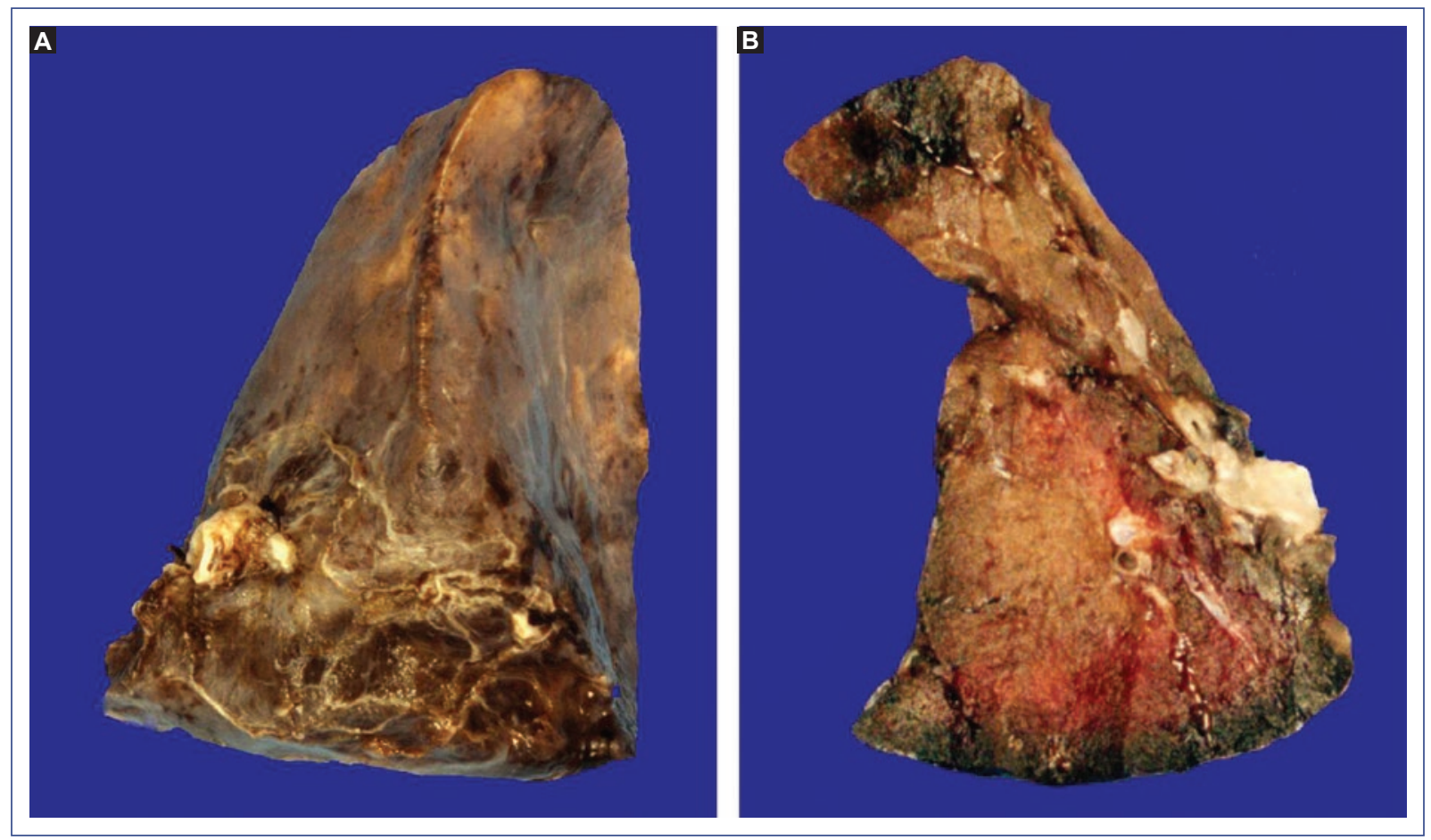

Figure 5. Macroscopic description. A. Surgical specimen of triangular shape, $41 \mathrm{~g}$, and $4 \times 3.5 \mathrm{~cm}$ size; the outer surface is entirely covered by pleura, which is smooth, bright, and grey in the basal portion of the lobe. Pulmonary cyst: nodular specimen of $1.5 \times 1 \times 0.3 \mathrm{~cm}$ size, soft, yellowish-white. B. It is observed a blood vessel, $0.3 \mathrm{~cm}$ in diameter, that penetrates the lung parenchyma; at the level of the pulmonary hilum, the main bronchus and venous vessels with thin walls are identified. After cyst dissection, a cystic cavity is observed, covered by a $0.3 \mathrm{~cm}$ thick wall. 


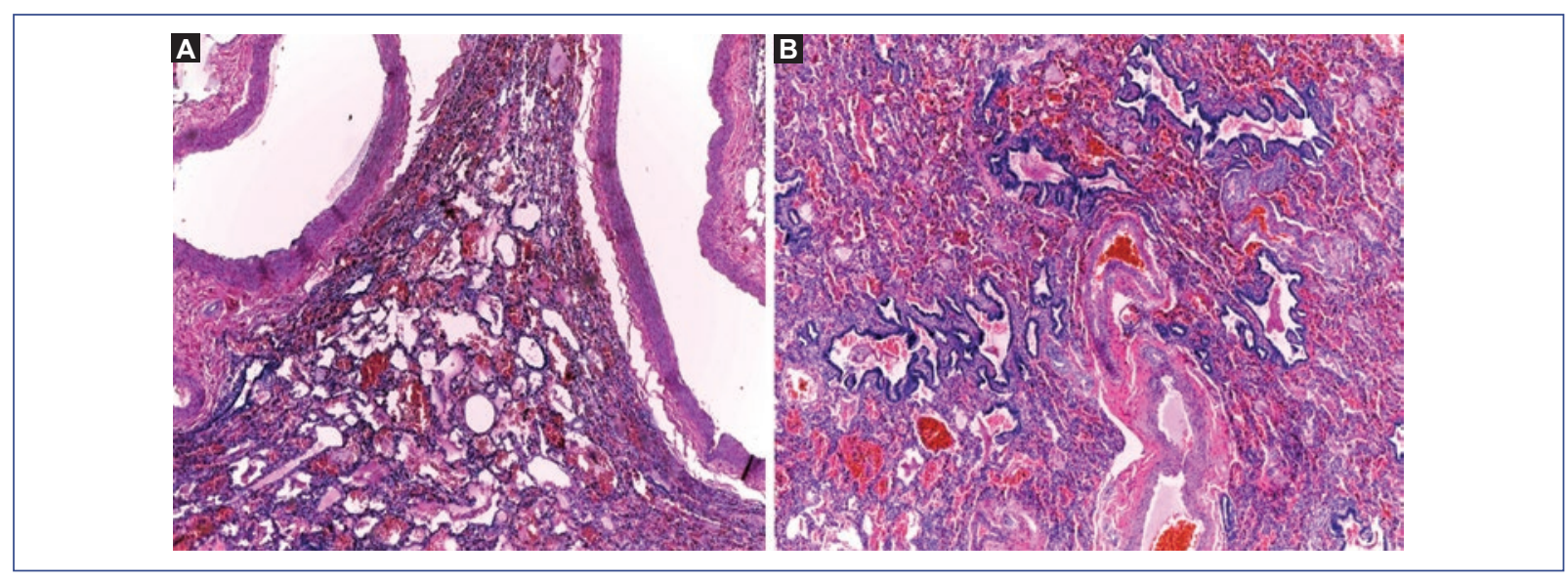

Figure 6. Microscopic description. A. Sections show a lobar hilum with artery, vein, and bronchus. The pulmonary vein presents irregular thickening due to muscle hyperplasia. Artery and bronchus without alterations. B. The section of the aberrant vessel corresponds to an artery with irregular fibrosis of the intima and muscle hyperplasia. The adjacent parenchyma shows an abnormal architecture due to the presence of cystic formations covered by ciliated cylindrical epithelium, collapse, and intraalveolar hemorrhage. In the rest of the parenchyma, it can be observed recent intraalveolar hemorrhage, overdistension of bronchioles and alveoli, also vascular disease data indicated by hypertrophy of the media and increased connective tissue in the pre-acinar arterioles adventitia. The cyst has a thick muscular wall lined by respiratory epithelium. Submucosal glands and islands of hyaline cartilage are observed in the wall.

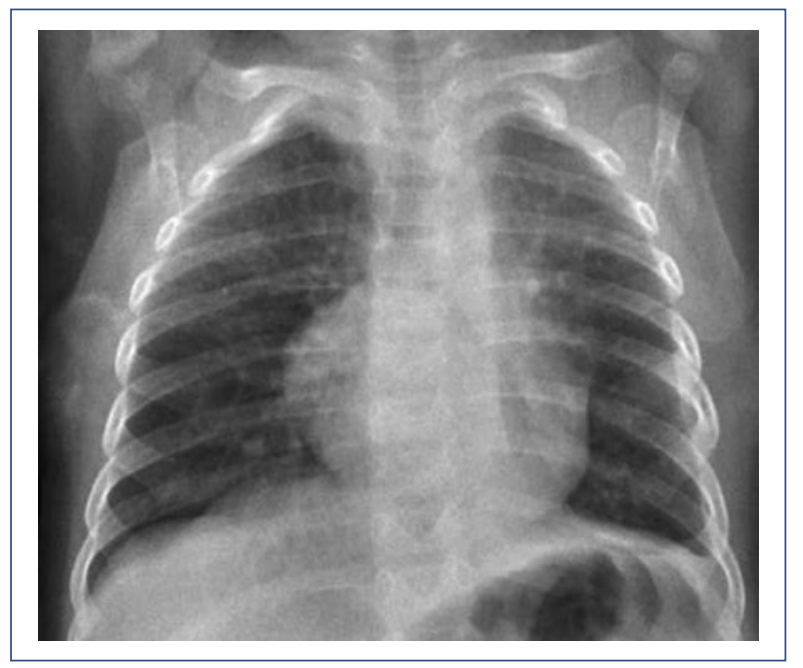

Figure 7. Chest x-ray. Posteroanterior projection. We observed the absence of radiopacities suggestive of masses, cystic lesions or displacement of the cardiac silhouette. Proper pulmonary reexpansion is shown.

attributed to an overgrowth of bronchioles, with suppression of alveolar development ${ }^{6}$.

Pulmonary sequestration represents $6 \%$ of congenital pulmonary malformations and has an estimated incidence of $0.15-1.7 \%$, while CPAM constitutes $25 \%$ of all congenital lung lesions ${ }^{3,4,7}$.
Concerning classification, there are two types of pulmonary sequestration extralobar and intralobar. Intralobar sequestration develops inside the lung, covered by visceral pleura, intimately connected to the adjacent lung. It is located at the lower lobes in $98 \%$ of cases and is associated with a diaphragmatic hernia, congenital heart anomalies, and $\mathrm{CPAM}^{6}$. This type of malformation occurs in $75 \%$ of cases.

Extralobar sequestration is a mass of lung tissue surrounded by its pleural investment; it occurs in $25 \%$ of cases $^{8}$. Usually, it is located in the posterior segments of the lower lobes. In $90 \%$ of cases, it is presented on the left side, and more frequently in the thorax. In the remaining cases, it has an intraabdominal location, specifically infradiaphragmatic and in the left adrenal region ${ }^{9}$.

In 1977, Stocker and Drake classified the CPAM, according to its clinical and pathological characteristics, into three types (types 1, 2 and 3$)^{10}$. Later, types 0 and 4 were added, according to the place of lesion origin ${ }^{11}$. Also, the congenital malformation of the pulmonary airway term was introduced due to the different characteristics of each type and the fact that cystic and adenomatoid lesions were not present in all types ${ }^{12}$.

Type 0 consists of structures similar to bronchi which represent acinar dysplasia or agenesis, they are rare, also associated with cardiovascular malformations, and they are incompatible with life. Type 1 
includes structures similar to bronchi and bronchioles with large cysts. They can be visualized in the first months of life, in children and young adults; they represent $65 \%$ of cases. Type $2(10-15 \%$ of cases) consists of bronchiolar and acinar structures. They are observed during the first year of life; some have a poor prognosis because of its association with abnormalities that are incompatible with life, such as renal agenesis; the cysts measure approximately 0.5 to $2 \mathrm{~cm}$. Type 3 (5\% of cases) is composed of bronchioles, ducts and alveolar sacs resembling acinar structures, which are visualized as small cysts of $0.2 \mathrm{~cm}$ or as solid structures. This type is observed during the first days or months of life; it is associated with polyhydramnios and fetal anasarca, also presents high mortality. Type $4(10-15 \%$ of cases) is a distal acini malformation that is seen as cysts with peripheral distribution and a hamartomatous appearance. It is diagnosed in newborns and up to 4 years of age, and it has been observed that it compromises only one lobe in $80 \%$ of cases; this type presents an excellent survival ${ }^{5}$.

The signs and symptoms of both extralobar and intralobar pulmonary sequestration can go unnoticed until the neonatal, school or adolescence period, with the appearance of recurrent pneumonias ${ }^{13}$. The CPAM expansive lesions lead to progressive symptomatology: if the lesions are large, they can compromise lung development in the fetal period producing hypoplastic lungs. Due to the mass-effect, they can impede adequate cardiac contractility and cause compression of the vena cava producing hydrops fetalis. If the lesions constrict the esophagus, they prevent the swallowing of the amniotic fluid and polyhydramnios will appear. Repeated pneumothorax, obstructive bronchitis, and chest pain have also been described, although less frequently ${ }^{14}$.

The diagnosis can be made prenatally by ultrasound, usually between 18-24 weeks of pregnancy. Pulmonary sequestration is visualized in prenatal ultrasounds as a hyperechoic mass in the basal and posterior regions of the affected hemithorax. Color Doppler ultrasound is helpful to determine the anomalous vessel. On chest $X$-ray, extralobar pulmonary sequestrations are seen as well-defined solid masses adjacent to the mediastinum or present at the cardiophrenic angle, sometimes subdiaphragmatic. However, they may be confused with mediastinal tumors. In contrast, intralobar pulmonary sequestrations may contain air, are usually more heterogeneous and less defined and can mimic pneumonia or lung abscess ${ }^{13,15}$. Bronchiectasis, subsegmental atelectasis, mediastinal shift, and enlargement of the ipsilateral pulmonary hilum can also be observed. Computerized tomography shows a cystic mass with air or fluid content, focal emphysema and hypervascularization of the affected tissue. Computed tomography with intravenous contrast demonstrates the presence of an anomalous vessel, shown as a linear structure that arises from the aorta ${ }^{6}$.

Using ultrasonography, CPAM can be identified as a solid or cystic mass in one of the fetal lungs or as a dominant cyst surrounded by smaller cysts. On a plain radiograph and computed tomography, the CPAM is observed as unilateral lesions with multiple rounded and thin-walled air cysts. Depending on the type of CPAM, the number and the size of the cysts vary ${ }^{14}$.

To date, surgery is still the treatment of choice for pulmonary sequestration and CPAM. Sancho-Hernández et al. reported that pulmonary sequestration has a poor involution capacity. They referred that since there are no clear prognostic indicators in the current literature on the malignant potential and the risk of infection of pulmonary sequestration and CPAM, expectant management remains an experimental option. Therefore, elective surgery could be recommended during early breastfeeding (less than six months), due to the favorable immunological profile at this age, rather than due to statistical circumstances ${ }^{16}$. San Vicente et al. have reported that surgical management should be the treatment of choice, even in asymptomatic cases, because of the risk of recurrence. In their experience, they reported a case with malignant degeneration ${ }^{17}$.

The association of pulmonary sequestration and CPAM has been described in approximately 40-60 cases, since its first description in $1949^{3,18}$. The most frequent association is between intralobar pulmonary sequestration and CPAM type 2. Furthermore, Zangwill and Stocker reported that of 30 cases of extralobar pulmonary sequestration, approximately $25 \%$ had an associated $\mathrm{CPAM}^{19}$. Conran and Stocker reported a coexistence of extralobar pulmonary sequestration and CPAM type 2 in more than $50 \%$ of cases $^{20}$. The joint presence of the two malformations indicates a common defect in embryological development $3,19,20$. Both are considered hybrid lesions and are diagnosed only by histopathology. Pathologically, these lesions show combined histological data ${ }^{16}$.

In the present case, the patient was diagnosed with pulmonary sequestration at week 24 of gestation. She received medical management at this stage, although it was not specified in her clinical record what type of intervention was performed. At this stage, in most 
cases, the successful resolution of the disease has been reported, which prevents procedures in the postnatal stage. There is no agreement on whether the intervention should be performed intrauterine or within a few months after birth, although most authors agree that if there are extensive lesions or if they produce hydrothorax, putting the fetus at risk, prenatal treatment should be carried out ${ }^{21}$. In contrast, clinical cases have been reported in which hydrothorax and hydrops are stopped, but the growth of abnormal lung tissue continues; in these cases, a thoracotomy and surgical removal in the early neonatal period should be performed $^{22}$.

The patient referred to in the present case did not present any symptoms during the first four months after birth. The important antecedent of fetal surgery motivated the parents to carry out the patient follow-up at the Pneumology department, where, in addition to the pulmonary sequestration, a CPAM inside the latter and a bronchogenic cyst were found in the histopathological study.

Based on the aforementioned, it is considered that patients with a prenatal history of pulmonary malformations should have a pneumology follow-up starting at the neonatal stage, even if they are asymptomatic. The prenatal diagnosis of these lesions is not a reliable predictor of their histopathological characteristics, so it is necessary to make a transoperative differential diagnosis and confirmatory histopathological diagnosis. Also, the exploration for associated diseases in all symptomatic and asymptomatic patients should be done ${ }^{16}$.

Accurately identifying the type of malformations provides valuable statistical data for future research; moreover, it helps to offer prompt management and adequate follow-up to the patient, as well as providing better guidance to families.

\section{Ethical considerations}

Permission was requested from the hospital authorities before carrying out the study, and the data obtained was kept confidential to avoid manipulation by persons not involved in the study.

\section{Conflicts of interest}

The authors declare no conflicts of interest.

\section{References}

1. Andrade CF, Ferreira HPC, Fisher GB. Malformaçiõnes pulmonares congênitas. J Bras Pneumol. 2011;37:259-71.

2. Giubergia V. Malformaciones pulmonares congénitas. Neumol Pediatr. 2014;9:88-94.

3. Sánchez Abuín A, Somoza I, Liras J, Méndez R, Tellado M, Ríos J, et al. Malformación adenomatoidea quística congénita asociada a secuestro pulmonar. Presentación de dos casos clínicos. Cir Pediatr. 2005; 18:39-41.

4. Cobos N, Perez-Yarza E.G. Malformaciones Broncopulmonares. In: Cobos N, Pérez-Yarza EG, editors. Tratado de neumología infantil. Madrid: Ergon; 2009. pp. 257.

5. Villamizar C, Cárdenas R, Rojas G, Méndez A, González C. Secuestro pulmonar asociado a malformación adenomatoidea quística. A propósito de un caso clínico. VITAE Acad Biom Dig. 2007;31.

6. Spina JC, Medina J, Cúneo L, Badano F, Bambaci F. Espacios aéreos pulmonares anormales por TCAR. Rev Argent Radiol. 2008;72:199-215.

7. Álvarez García N, Escartín Villacampa R, Fernández Atuán R, Sainz Samitier A, Elías Pollina J. Secuestro pulmonar extralobar infradiafragmático. An Pediatr. 2014;80:410-1.

8. González R, Saldías R, Alarcón E, Seguel E, Stockins A, Gyhra SA, et al. Secuestro pulmonar: 8 casos. Rev Chil Cir. 2004;56:237-42.

9. McAteer J, Stephenson J, Ricca R, Waldhausen J, Gow K. Intradiaphragmatic pulmonary sequestration: advantages of the thoracoscopic approach. J Pediatr Surg. 2012;47:1607-10.

10. Stocker JT, Drake RM. Congenital cystic adenomatoid malformation of the lung. Classification and morphologic spectrum. Hum Pathol. 1977; 8:155-71.

11. Stocker JT. Cystic lung disease in infants and children. Fetal Pediatr Pathol. 2009;28:155-84.

12. Guzmán-Vélez JE, Ossa-Galvis MM. Malformación congénita de la vía aérea pulmonar. Rev CES Med. 2014;28:283-92.

13. Suarez Traba O, Pérez Vigara A, Parrón M, Bret Zurita M, Tovar Larrucea JA, Prieto Arellano C. Malformaciones congénitas broncopulmonares ¿qué debe conocer el radiólogo? Congreso de la Sociedad Española de Radiología Médica (SERAM). Granada: 2012; poster 1. Available at: www.1594/seram2012/S-0666.

14. Díaz M, Aguirre J, Bonilla K. Pulmón hiperlúcido unilateral congénito en pediatría, hallazgos en imagen a propósito de cinco casos. Rev Fed Ecuat Soc Radiol. 2015;10:18-25.

15. Mayoral Campos V, Carro Alonso B, Guirola Ortiz JA, Benito Arévalo JL. Secuestro pulmonar. Arch Bronconeumol. 2013;3:129-30.

16. Sancho-Hernández R, Solorio-Rodríguez L, Durán-Colín AA, Iribe-Gaxiola Y, Cuevas-Schacht FJ, López-Corella E. Secuestro pulmonar extralobar asintomático y la importancia del diagnóstico y tratamiento perinatal: el manejo expectante no es una opción terapéutica. Neumol Cir Tórax. 2015;74:262-70.

17. San Vicente B, Bardaji C, Obiols P, Abad P, Rigol S. Malformación adenomatoidea quística: ¿somos capaces de prever su evolución? Cir Pediatr. 2009;22:87-92.

18. Ormazabal Ramos JC, Lupiani Castellanos MP, Hernández-Siverio Gonzales N, Martin Mederos JI, Herrera Montes I. Diagnóstico prenatal en un caso de secuestro pulmonar intralobular asociado con malformación adenomatoidea quística. Acta Pediatr Esp. 2003;61:261-4.

19. Zangwill BC, Stocker T. Congenital cystic adenomatoid malformation within an extralobar pulmonary sequestration. Pediatr Pathol. 1993; 13:309-15.

20. Conran RM, Stocker T. Extralobar sequestration with frequently associated congenital cystic adenomatoid malformation, type 2: report of 50 cases. Pediatr Develop Pathol. 1999;2:454-63.

21. Herranz-Barbero A, Gómez-Martínez de Lecea C, Tamura A, Torre Buxalleu W, Alzina de Aquilar V. Tratamiento quirúrgico del secuestro pulmonar extralobar de diagnóstico prenatal. An Sist Sanit Navarra. 2012;35:309-12

22. Nicolini U, Cerri V, Groli C, Poblete A, Mauro F. A new approach to prenatal treatment of extralobar pulmonary sequestration. Prenat Diagn. 2000;20:758-60 